\title{
Factors Affecting Work Satisfaction and Employee Performance in Automotive Industrial Chain
}

Submitted 10/02/20, 1st revision 05/03/20, 2nd revision 28/03/20, accepted 22/04/20

\author{
Indrayani ${ }^{1}$, Awis $\mathrm{Al}$ Qarny ${ }^{2}$
}

\begin{abstract}
:
Purpose: This study aimed to analyze the determination of compensation, motivation and organizational commitment to employee performance and job satisfaction as an intervening variable.

Design/methodology/approach: The statistical method used is the Structural Equation Model with a total sample of 112 respondents. This study uses a questionnaire to measure the factors affecting work satisfaction as compensation, motivation, organizational commitment, job satisfaction and employee performance.

Findings: The results of this study found that there were positive and significant effects of compensation on the job satisfaction, and organizational commitment to job satisfaction as well as the effect of motivation on employee's performance. Moreover, the insignificant effect is found in the effect of the job satisfaction on employee performance, the motivation on the job satisfaction, the compensation towards the employee performance and the organizational commitment on the employee performance. Mediation test proves that the job satisfaction is able to mediate the effects of compensation, motivation and organizational commitment on employee performance.

Practical Implications: The results of this study can be the basis for the management of automotive product distributors in Batam City to increase compensation, and motivation for employees to improve job satisfaction and company performance.

Originality/value: This study confirms the result that there are positive and significant effects of compensation on job satisfaction and organizational commitment to job satisfaction, and the effect of motivation on employee's performance.
\end{abstract}

Keywords: Compensation, motivation, organizational commitment, job satisfaction, employee's performance.

JEL: G32, H21, C33, O54, G30.

Paper Type: Research article.

\footnotetext{
${ }^{1}$ Faculty of Economics, Universitas Batam, Riau Islands, Indonesia, email: yaniindra@gmail.com

${ }^{2}$ Faculty of Economics, Universitas Batam, Riau Islands, Indonesia.
} 


\section{Introduction}

HR management in modern organizations requires employers to be able to establish good cooperation internally and externally. This cooperation will affect the company's efforts to ensure the achievement of company goals while maintaining employee commitment. Sustainability of this relationship also leads to material forms in various forms of giving to employees as feedback for their work (Strebel, 1996). The result, compensation and motivation become a necessity in a company, because it can affect the satisfaction and work performance of employees (Herzberg, 2008: Bernadus et al., 2018; Suryanto et al., 2017; Suryanto and Thalassinos, 2017). Motivation can increase one's job satisfaction because motivation is the spirit and encouragement of someone's external arising from himself, such as feelings and encouragement such as satisfaction felt, encouragement to responsibility for the family so motivated to work harder, to be more accomplished and encouragement to get what he expected like a career, a high position etc. This is in accordance with the theory that motivation can be interpreted as a mental state and mental attitude of humans who provide energy, encourage activities and lead or channel behavior towards achieving needs that give satisfaction or reduce imbalances (Siswanto, 2011).

This study aims to analyze the effect of compensation on job satisfaction, the effect of determining motivation, the influence of organizational commitment on job satisfaction, the effect of compensation on employee performance, the effect of motivation on employee performance, the influence of organizational commitment on employee performance, the effect of job satisfaction on employee performance, and the mediating effect of job satisfaction on the relationship between compensation, motivation and organizational commitment to employee's performance. This study took the object of automotive product distributors in Batam City, Indonesia.

\section{Literature Review}

\subsection{Relationship between Job Satisfaction and Employee's Performance}

Researchers at Cornell University developed the Job Descriptive Index (JDI) to assess a person's satisfaction with several dimensions: work, salary, promotion, coworkers and supervision. Jones (2006) believes that satisfaction causes performance or performance causes satisfaction. Vecchio (1995) states that job satisfaction is a thought, feeling, and tendency of an action, which is a person's attitude towards work. Kreitner and Kinicki (2014) stated that job satisfaction is an emotional response to various aspects of one's work. This supports Dhermawan et al. (2012) presenting that job satisfaction had a significant and significant effect on performance, then supported by data from Knez and Simester (2001) in Kinicki and Kreitner (2014) involving 54,417 employees showing that job satisfaction and performance have a fairly strong relationship. This is an important finding because it supports the belief that job satisfaction is a work attitude that is important and must be considered by managers when wanting to improve employee's performance (Suharno and Dini, 2018). 


\subsection{Relationship of Compensation with Job Satisfaction}

Compensation financially and non-financially is the right of employees if the employees have fulfilled their obligations at work. Compensation is a sensitive thing, but it can have an impact on job satisfaction, but on the contrary if the employee is not satisfied with the compensation received or does not feel there is justice in giving compensation it will have a negative impact on the company. Samudera et al. (2014) argues that compensation is all gifts from companies or organizations, both in the form of financial or not non-financial compensation to employees as remuneration for work done for the company. This is supported by Nurcahyani and Adnyani (2016) stating that compensation has a significant and significant effect on job satisfaction.

\subsection{Motivation with Job Satisfaction}

Employee satisfaction arises as a result of their needs being met, recognition of the resulting performance is also a driving factor for employees to be more productive in the company. Motivation is believed to have a positive influence on employee job satisfaction (Nurcahyani and Adnyani, 2016). If the work motivation of the employee is higher, then job satisfaction will increase, and vice versa if the work motivation of the employee is low or decreases, the satisfaction of work will be weak. According to Wibisono (2015) motivation is a term used to indicate the existence of a number of drives, desires, needs and strengths. Nurcahyani and Adnyani (2016) stated that work motivation is something that raises encouragement or morale, and it was proven that motivation had a positive and significant effect on job satisfaction.

\subsection{Organizational Commitment with Job Satisfaction}

Employees will feel protected, comfortable, safe, confident for a career in the company, so the company is very meaningful to employees, when the company clings to its commitment. Organizational commitment is also defined by Allen and Mayer $(1993 ; 2009)$ as a form of employee's love for the workplace. According to Colquitt et al. (2011), organizational commitment influences the desire of employees to remain members of the organization or leave the organization to pursue other jobs. Kinicki and Kreitner (2014) stated that organizational commitment has a positive and strong direction towards job satisfaction. This is supported by Djamaludin (2009) stating that there was an influence of organizational commitment to job satisfaction. Nonetheless, if the organization is not committed to employees, many employees will decide to leave the organization, as a result of dissatisfaction (Robbins, 2008). Therefore, the research hypotheses are:

H1: There is a significant effect of compensation on job satisfaction.

H2: There is a significant effect of motivation on job satisfaction.

H3: There is a significant influence of organizational commitment to job satisfaction. 
H4: There is a significant effect of compensation significantly on employee's performance.

H5: There are significant motivational influences on employee's performance.

H6: There is a significant influence of organizational commitment on employee's performance.

H7: Job satisfaction determines significantly the performance of employees.

H8: Job satisfaction mediates the effect of compensation, motivation and organizational commitment on employee's performance.

\section{Methodology}

In this study the population was 112 employees. The smpling technique used in this study is saturated sampling, which is a sampling technique where all members of the population are used as samples. The instrument used by researchers in collecting data is the use of questionnaires. By distributing questionnaires to the respondents and made in the form of a closed statement, each object is asked to choose one alternative answer that has been determined. The method in this study is to use quantitative methods with statistical tools to test the research hypotheses as steted above with version 24 of Structural Equation Model (SEM) and version 20 of Statistical Product and Service Solution (SPSS).

\section{Results}

\subsection{Evaluation of Goodness of Fit}

From the modification of the goodness of fit model there are four criteria that meet the goodness of fit model requirements, namely Chi-square $\left(\chi^{2}\right)$, Relatitive Chi-square $\left(\chi^{2} / \mathrm{df}\right)$, RMSEA and TLI while there are other four on the marginal level, namely the significance level, GFI, AGFI and CFI. Because there are four criteria fulfilling and four on the marginal level they are enough to accept the standard of goodness of fit.

Table 1. Goodness of Fit

\begin{tabular}{|l|l|l|l|}
\hline Goodness of Fit Index & Cut-of Value & Result Model & Information \\
\hline Chi-square $\left(\chi^{2}\right)$ & small & $\left.417.934^{*}\right)$ & Fit \\
\hline Relatitive Chi-square $\left(\chi^{2} / \mathrm{df}\right)$ & $\leq 3.00$ & $\left.1.64^{*}\right)$ & Fit \\
\hline Sig & $>0.05$ & 0.00 & Marginal \\
\hline RMSEA & $\leq 0.08$ & $\left.0.076^{*}\right)$ & Fit \\
\hline GFI & $\geq 0.90$ & 0.775 & Marginal \\
\hline AGFI & $\geq 0.90$ & 0.713 & Marginal \\
\hline TLI & $\geq 0.94$ & $0.920^{*}$ & Fit \\
\hline CFI & $>0.94$ & 0.775 & Marginal \\
\hline
\end{tabular}

Source: Own calculations. 


\subsection{Hypotheses Testing}

The effect of the compensation on the job satisfaction has a regression weight of 0.415 with C.R of 4.001 at sig $=0.00$. The value of C.R is $4.001>1.982$ and $\mathrm{sig}=0.00<0.05$ indicating that the effect of the compensation on the job satisfaction is significantly positive. The findings of this study indicate that compensation has a positive influence on job satisfaction where employees are eligible for obtaining remuneration in accordance with regulations or agreements. Empirical findings on employees received salaries according to standards with their positions and tenure, adequate facilities, reasonable and fair benefits have shown that compensation provided has an effect on employee's job satisfaction.

The effect of the motivation on the job satisfaction has a regression weight of 0.173 , with C.R of 1.355 at sig $=0.175$. The value of C.R is $1.355<1.982$ and $\mathrm{sig}=0.175>0.05$ indicating that the effect of the motivation on the job satisfaction is positively insignificant.

Table 2. Regression Weight and Direct Effect

\begin{tabular}{|l|l|l|l|l|l|}
\hline $\begin{array}{l}\text { Dependent } \\
\text { Variables }\end{array}$ & $\begin{array}{l}\text { Independent } \\
\text { Variables }\end{array}$ & $\begin{array}{l}\text { Direct } \\
\text { Effect }\end{array}$ & C.R. & P (Sig) & Information \\
\hline SAT & COMP & .415 & 4.001 & $* * *$ & Accepted \\
\hline SAT & COMT & .360 & 2.402 & .016 & Accepted \\
\hline SAT & MOT & .173 & 1.355 & .175 & Rejected \\
\hline PERF & COMP & .001 & 1.991 & .999 & Rejected \\
\hline PERF & SAT & .098 & .725 & .468 & Rejected \\
\hline PERF & MOT & .643 & 4.373 & $* * *$ & Accepted \\
\hline PERF & MEN & .081 & .507 & .612 & Rejected \\
\hline $\begin{array}{l}\text { *COMP=compensation; COMT= commitment; MOT=motivation; SAT=satisfaction; } \\
\text { PERF=performance }\end{array}$
\end{tabular}

Source: Own calculations.

The effect of the organizational commitment on the job satisfaction has a regression weight of 0.360 , with C.R of 2.402 at sig= 0.016. The value of C.R is $2.402>1.982$ and sig $=0.016<0.05$ indicating that the effect of the compensation on the job satisfaction is significantly positive. The findings of this study confirm that organizational commitment has an influence on job satisfaction, commitment is a promise that must be honored to employees where the company commits and is responsible for the future retaining the employees at work. The empirical findings that employees are working with lot of excitement even though there is one condition in the company's climate not improved, however employees have the urge to keep working more optimally.

The effect of compensation on employee performance has a regression weigh of 0.001 , with C.R of 1.991 at sig $=0.999$. The C.R value of $1.991>1.982$ and sig $=0.999>0.05$ 
indicate that the effect of the compensation on employee performance is positively insignificant. This is supported by Nurcahyani and Adnyani (2016) stating that it directly and significantly affects performance.

The effect of the motivation on employee's performance has a regression weight of 0.643 , with C.R of 4.373 at $\mathrm{sig}=0.00$. The value of C.R is $4.373>1.982$ and sig= $0.00<0.05$ indicating that the effect of the motivation on the variable employee's performance is significantly positive. The findings of this study indicate that motivation in the company influences employee's performance. Such conformity with motivation theory is a factor that encourages a person to do a certain activity, therefore motivation is often interpreted as a driving factor for employee's behavior (Sutrisno, 2015). Individual behavior driven by the need for achievement will be seen where trying to do something in new and creative ways, looking for feedback about his actions, choosing risks that are moderate in these actions by choosing the current risks there are still opportunities for higher achievement by taking personal responsibility for these actions. The empirical findings show that employees still exhibit eager behavior to work and create good relationships with fellow colleagues.

\section{Figure 1. Full Model SEM}



Source: Own calculations.

The effect of organizational commitment on employee's performance has a regression weight of 0.081 , with C.R of 0.507 at $\mathrm{sig}=0.612$. The value of C.R is $0.507<1.982$ and sig $=0.612>0.05$ indicating that the effect of the organizational commitment on employee's performance is positively insignificant. These findings indicate that 
organizational commitment has a positive effect on performance, meaning that when a company is committed to its promise, employee's performance will increase and employees feel protected, comfortable, safe, confident for a career in the company, so that the company is very important to employees, when the company adheres to its commitment. Jernigan et al. (2001) and Djamaludin (2009) stated that high organizational commitment will positively correlate with performance. This statement is supported by Djamaludin (2009) said that organizational commitment has a positive correlation. The empirical findings of the commitment are insignificant where some employees feel that they cannot always depend on the company, there is a mass of time coupled with management at certain times not commit to employees while carrying out their duties.

The effect of job satisfaction on employee performance has a regression weight of 0.098 , with C.R of 0.725 at sig= 0.468 . The value of C.R is $0.725<1.982$ and sig= $0.468>0.05$ indicating that the effect of the job satisfaction on employee's performance is positively insignificant. Employee's job satisfaction must be created as well as possible so that work morale, dedication, love, and employee performance increase. Job satisfaction is an emotional attitude that is fun and love for his job. This attitude is reflected by work morale, discipline and employee performance. Job satisfaction is enjoyed in work, outside of work and a combination of in and outside work, while there is no absolute level of measurement because each individual employee has different standards of satisfaction (Hasibuan, 2010).

Table 3. Indirect Effect (Relationships Effect)

\begin{tabular}{|l|l|l|l|l|l|}
\hline $\begin{array}{l}\text { Variable } \\
\text { Dependent }\end{array}$ & $\begin{array}{l}\text { Independent } \\
\text { Variables }\end{array}$ & $\begin{array}{l}\text { Indirect } \\
\text { Effect }\end{array}$ & C.R. & P (Sig) & Information \\
\hline PERF & COMP & .033 & .001 & .999 & Rejected \\
\hline PERF & MOT & .014 & 4.373 & $* * *$ & Accepted \\
\hline PERF & COMT & .034 & .507 & .612 & Rejected \\
\hline
\end{tabular}

Source: Own calculations.

\subsection{Mediating Effect of Job satisfaction}

Job satisfaction mediates the effects of compensation, motivation and organizational commitment on employee's performance. Herzberg (2008) states that humans have two collections of needs, the first being related to job satisfaction, and the second is related to job dissatisfaction. Indicators that affect satisfaction in work are the success of implementation, recognition, work itself, responsibility and development. In contrast, the factors that do not bring satisfaction to work called Herzberg (2008) as hygiene factors, are company policy and administration, supervision, salary, personal relationships with supervisors, and working conditions. In today's company, many policies that are very detailed in managing employees are policies made by company management. These policies make employees who have high work motivation so that they do not give effect to employees significantly. 
The test results through Analysis Measurement with Determination with Square Multiple Correlation show an Estimate value of 0.667 for job satisfaction, and 0.605 for performance. Thus it can be stated that job satisfaction and changes in employee performance by compensation, motivation and organizational commitment amounted to $66.7 \%$ and $60.5 \%$, respectively.

\section{Conclusion}

The results of this study found that there were positive and significant effects of compensation on the job satisfaction, organizational commitment to job satisfaction, and motivation on employee's performance. Whereas, the insignificant effect is found in the effect of the job satisfaction on employee's performance, the motivation on the job satisfaction is positive, the compensation towards the employee performance and the organizational commitment on the employee performance. Mediation test proves that the job satisfaction is able to mediate the effects of compensation, motivation and organizational commitment on employee's performance.

\section{References:}

Bernadus, D., Utami, C.W., Liliana. 2018. Factor analysis of ownership behavior at family business: The case of Indonesia. International Journal of Economics and Business Administration, 6(2), 27-38.

Colquitt, J., Lepine, J.A., Wesson, M.J., Gellatly, I.R. 2011. Organizational behavior: Improving performance and commitment in the workplace, Vol. 375. New York, NY, McGraw-Hill Irwin.

Dhermawan, A.A.N.B., Sudibya, I.G.A., Utama, I.W.M. 2012. Effect of motivation, work environment, competence, and compensation on job satisfaction and employee performance in the Office of Public Works of the Province of Bali. Matrix: Management Journal, Business Strategy and Entrepreneurship.

Djamaludin, M. 2009. Effect of Organizational Commitment, Career Development, Work Motivation and Individual Characteristics on Job Satisfaction and Employee Performance of East Halmahera Regency Government. Journal of Economics and Management, 5(3).

Hasibuan, M. 2010. Human Resource Management. Jakarta, PT Bumi, Aksara.

Herzberg, F. 2008. One more time: How do you motivate employees? Harvard Business Review Press.

Jernigan, III, I.E., Beggs, J.M., Kohut, G.F. 2002. Dimensions of work satisfaction as predictors of commitment type. Journal of Managerial Psychology, 17(7), 564-579.

Jones, M.D. 2006. Which is a better predictor of job performance: job satisfaction or life satisfaction? Journal of Behavioral and Applied Management, 8(1).

Kinicki, A., Kreitner, R. 2014. Perilaku organiComp. Penerbit Salemba. Jakarta.

Knez, M., Simester, D. 2001. Firm-wide incentives and mutual monitoring at Continental Airlines. Journal of Labor Economics, 19(4), 743-772.

Kurniawan, I.A., Azzuhri, M. 2012. Organizational Culture and Compensation: Its Effects on Employee Motivation and Performance (Study at PT Sang Hyang Series Regional Office III Malang). FEB Student Scientific Journal, 1(2).

Mathis, R.L., Jackson, J.H. 2011. Human Resource Management. Jakarta, Salemba Empat. 
Meyer, J.P., Allen, N.J., Smith, C.A. 1993. Commitment to organizations and occupations: Extension and test of a three-component conceptualization. Journal of applied psychology, 78(4), 538-551.

Mukzam, M.D., Samudera, A.P., Rahardjo, K. 2014. Effect of Financial Compensation on Performance (Study of Employees at PT. Bank Jatim Malang Branch). Business Administration Journal, 7(2).

Nurcahyani, N.M., Adnyani, I.D. 2016. Effect of compensation and motivation on employee performance with job satisfaction as an intervening variable. Management EJournal, 5(1).

Robbins, S.P. 2008. Organizational Behavior and Management. Jakarta, Gramedia.

Siswanto, H.B. 2011. Introduction to Management. Jakarta, Bumi Aksara.

Strebel, P. 1996. Why do employees resist change? Harvard business review, 74(3), 86.

Suharno, P., Dini, I. 2018. The Influence of Work Stress, Working Cost, Compensation and Work Discipline on Employee' Productivity. International Journal of Economics and Business Administration, 6(4), 62-75.

Suryanto, T., Thalassinos, E.J., Thalassinos, I.E. 2017. Board Characteristics, Audit Committee and Audit Quality: The Case of Indonesia. International Journal of Economics \& Business Administration, 5(3), 47-57.

Suryanto, T., Thalassinos, I.E. 2017. Cultural Ethics and Consequences in Whistle-Blowing among Professional Accountants: An Empirical Analysis. Journal of Applied Economic Sciences, 6(52), 1725-1731.

Vecchio, R.P. 1995. The impact of referral sources on employee attitudes: Evidence from a national sample. Journal of Management, 21(5), 953-965.

Wibisono, C. 2015. Human Resource Management as Spiritual Motivation. Medan, First Publisher. 